\title{
ECOLOGICAL SPECTRUMS OF HETEROTROPHIC FLAGELLATES (PROTISTA) IN WATER BODIES OF UKRAINIAN POLISSYA AREA
}

\author{
S. Yu. Shevchuk ${ }^{1}$, I. V. Dovgal ${ }^{2}$ \\ ${ }^{1}$ I. Franko Zhytomyr State University, \\ Pushkin str., 42, Zhytomyr, 10002 Ukraine \\ E-mail: zhgutik@mail.ru \\ ${ }^{2}$ Schmalhausen Institute of Zoology NAS of Ukraine, \\ B. Chmielnicki str., 15, Kyiv, 01601 Ukraine \\ E-mail:dovgal@izan.kiev.ua
}

Received 25 February 2010

Accepted 8 June 2010

\begin{abstract}
Ecological Spectrums of Heterotrophic Flagellates (Protista) in Water Bodies of Ukrainian Polissya Area. Shevchuk S. Yu., Dovgal I. V. - Dependence of 26 heterotrophic flagellate species development in central part of Ukrainian Polissya area from operating $\mathrm{pH}$ and concentrations of dissolved organic matter and oxygen in the waters is considered. Narrowing of existence spectrums in certain types of water body characteristic for some species of heterotrophic flagellates is stated; this peculiarity is strongly expressed in the bogs where specific complex of hydrochemical conditions to have a place.
\end{abstract}

Key words: heterotrophic flagellates, Ukraine, ecological spectrums, tolerance.

\begin{abstract}
Экологические спектры гетеротрофных флагеллат (Protista) в водоемах Украинского Полесья. Шевчук С. Ю., Довгаль И. В. - Приведены сведения о толерантности видов гетеротрофных жгутиковых центральной части Украинского Полесья к гидрохимическим факторам, таким как $\mathrm{pH}$, содержание растворенных в воде кислорода и органических веществ. Получены экологические спектры для 26 видов флагеллат, иллюстрирующие их отношение к указанным факторам. Показано, что для ряда изученных видов характерно сужение экологических спектров в отдельных типах водоемов, что особенно проявляется в болотах с их специфическим комплексом условий.
\end{abstract}

Ключевые слова: гетеротрофные флагеллаты, Украина, экологические спектры, толерантность.

\section{Introduction}

The heterotrophic flagellates are widely distributed in the water bodies of different modes. The group is of great importance in the cycle of organic matter since these protozoans present the important link in the food chains between bacterial plankton and phytoplankton on the one hand and mesoplankton on the other one (Fenchel, 1987).

The additive effect of several factors of aquatic environment is responsible for both of the species richness and abundance of heterotrophic flagellates as for peculiarities of their distribution.

Particularly, it is known that different flagellate species are characteristic by various attitudes to the operating $\mathrm{pH}$. It has been found experimentally that kinetoplastids developing in the operating $\mathrm{pH}$ range between 4 and 10 with optimum between 7 and 8 (Zhukov, 1993). The species richness of heterotrophic flagellates in the natural water bodies with subacid reaction was higher than in water bodies with neutral reaction (Mylnikov, Kosolapova, 2004).

Many of heterotrophic flagellates are inhabitants of polluted waters and unpretentious concerning concentration of dissolved $\mathrm{O}_{2}$. Among them the benthic and periphytic flagellate species generally are less sensitive to oxygen concentration than planktonic. However there is no clear dividing line between these ecological groups (Zhukov, 1993).

The facultative and obligate anaerobes mainly from the order Diplomonadida Wenyon, 1926 represent the peculiar ecological group of heterotrophic flagellates (Fenchel, 1987). 


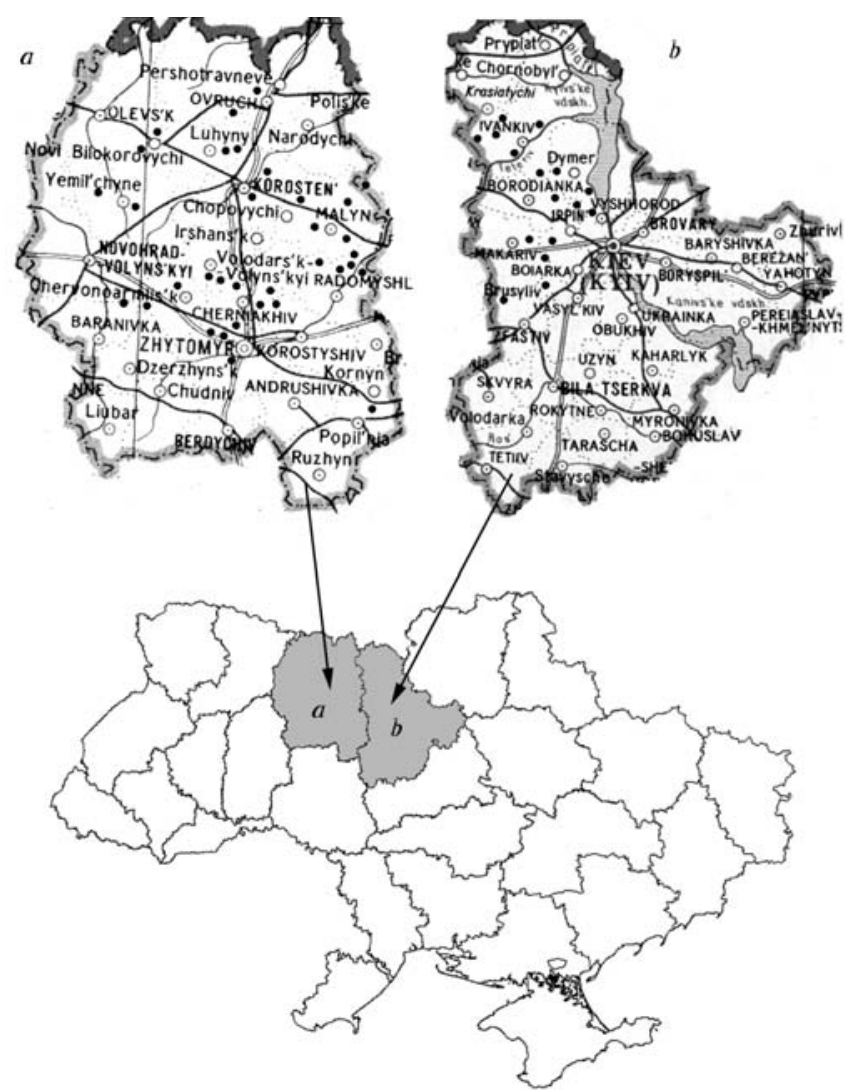

Fig. 1. Map showing the collection sites (marked by black spots) of heterotrophic flagellates in the investihated region. $a-$ Zhytomyr Region; $b-$ Kyiv Region.

Рис. 1. Пунткы сбора материала (отмечены черными точками) по гетеротрофнм флагеллатам. $a-$ Житомирская область; $b-$ Киевская область.

The cultured heterotrophic flagellates usually show the positive dependence of their development with concentration of dissolved organic matter (Zhukov, 1970), but optimum of concentration may vary essentially in different species (Kosolapova, 2005). Species richness, abundance and biomass of flagellates increasing with grows of organic matter content in the water, as Tikhonenkov (2006) shows in his work on the natural water bodies.

However the data concerning tolerance of flagellate species to hydrochemical characteristics are incomplete (Tikhonenkov, 2006) and generally apply to impact of any environmental factors on flagellate community as a whole.

Here, we consider dependence of development of several heterotrophic flagellate species from the central part of Ukrainian Polissya area from operating $\mathrm{pH}$ and concentrations of dissolved organic matter and oxygen in the waters.

\section{Material and methods}

The material was collected in different types of water bodies in the 53 localities of Zhytomyr and Kyiv Regions of Ukraine (fig. 1) during 2004-2007. At each locality the samples of water were sampling by hand in three replications. The flagellate species identification and enumeration were carried out in vitro.

For the estimation of heterotrophic flagellate abundance in $5 \mathrm{ml}$ of water were placed in Petri dishes with diameter $6 \mathrm{~cm}$. Fifteen microscopic fields were examined under light microscope MIKMED (using water immersion objective) at magnification x1050 in each Petri dish. The abundance of flagellate cells per $1 \mathrm{ml}(\mathrm{N})$ was calculated by the following equation:

$$
N=n \cdot S / V \cdot S
$$

where $\boldsymbol{n}$ is the overall abundance of cells in characters, $\boldsymbol{S}$ is the area of the Petri dish, $\boldsymbol{V}$ is the sample volume, $\boldsymbol{s}$ is the overall area of characters (Zhukov, 1975).

The flagellates were identified based on the keys by Z. I. Asaul (1975), B. F. Zhukov (1993), A. P. Mylnikov (1992) and A. P. Mylnikov, N. G. Kosolapova (2004). 
Table 1. The score scale of some abiotic factor values

Табли ц 1. Бальная шкала значений абиотических факторов

\begin{tabular}{c|c|c|c|c}
\hline \multirow{2}{*}{ Score } & \multicolumn{4}{|c}{ Factor values } \\
\cline { 2 - 5 } & Temperature, ${ }^{\circ} \mathrm{C}$ & $\mathrm{pH}$ & $\begin{array}{c}\text { Dissolved } \mathrm{O}_{2} \text { concentration } \\
(\mathrm{mg} / 1)\end{array}$ & $\begin{array}{c}\text { Dissolved ogranic matter concentra- } \\
\text { tion (by permanganat oxidation in } \\
\left.\mathrm{mg} / 1 \text { of } \mathrm{O}_{2}\right)\end{array}$ \\
\hline 1 & $17.0-17.9$ & $5.10-5.25$ & $2.60-4.70$ & $4.70-14.70$ \\
2 & $18.0-18.9$ & $5.26-5.51$ & $4.80-6.90$ & $14.80-24.80$ \\
3 & $19.0-19.9$ & $5.52-5.77$ & $7.00-9.10$ & $24.90-34.90$ \\
4 & $20.0-20.9$ & $5.78-6.03$ & $9.20-11.30$ & $35.00-45.00$ \\
5 & $21.0-21.9$ & $6.04-6.29$ & $11.40-13.50$ & $45.10-55.10$ \\
6 & $22.0-22.9$ & $6.30-6.55$ & $13.60-15.70$ & $55.20-65.20$ \\
7 & $23.0-23.9$ & $6.56-6.81$ & $15.80-17.90$ & $65.30-75.30$ \\
8 & $24.0-24.9$ & $6.82-7.07$ & $18.00-20.10$ & $75.40-85.40$ \\
9 & $25.0-25.9$ & $7.08-7.33$ & $20.20-22.30$ & $85.50-95.50$ \\
10 & $? 26.0$ & $7.33-7.60$ & $22.40-24.50$ & $95.60-105.60$ \\
\hline
\end{tabular}

Water temperature was measured with calibrating mercurial thermometers graduated in 0.1 or $0.5^{\circ} \mathrm{C}$, whereas operating $\mathrm{pH}$ measured with the $\mathrm{pH}-150 \mathrm{M} \mathrm{pH}$-meter, dissolved oxygen concentration calculated by the Winkler method, and dissolved organic matter measured by permanganate oxidation (Alekin et al., 1973; Unifitcirovannye..., 1983).

For the graphic expression of the species ecological spectrums the values of quantity of different environmental factors were brought to the connatural units. With that end in view we used the ten-point linear scales (Pesenko, 1982) constructed on base on own data of factor values.

The constructed scales and becoming ranges of factor values are given in table 1.

\section{Results and discussion}

The tolerances for above listed factors were estimated in 26 most common in the region flagellate species (Shevchuk, 2007): Bodo globosus Stein, 1878; B. designis Skuja, 1948; B. saltans Ehrenberg, 1838; Rhynchomonas nasuta (Stokes, 1888) Klebs, 1893; Rhynchobodo simius Patterson et Simpson, 1996; Parabodo nitrophilus Skuja, 1948; Entosiphon sulcatum (Dujardin, 1841) Stein, 1878; Peranema fusiforme (Larsen, 1987) Larsen et Patterson, 1990; Petalomonas minuta Hollande, 1942; P. pusilla Skuja, 1948; Notosolenus sp.; Cercomonas crassicauda (Alex.) Lemm., 1914; C. longicauda (Duj.) Senn, 1880; Heteromita reniformis (Zhukov, 1978) Mylnikov, 2000; Allantion tachyploon Sandon, 1924; Protaspis gemmifera Larsen et Patterson, 1990; P. simplex Vörs, 1992; Monosiga ovata Kent, 1880; Goniomonas truncata (Fresenius) Stein, 1887; Paraphysomonas vestita (Stokes, 1888) De Saedeleer, 1929; Spumella major (Skua, 1956) Zhukov, 1993; S. vivipara (Ehrenb.) Pascher, 1912; Phyllomitus apiculatus Skuja, 1948; Ancyromonas contorta (Klebs) Lemmermann, 1910; A. sigmoides Kent, 1880 and Apusomonas proboscidea Alexeieff, 1924.

The ranges of factor values for different heterotrophic flagellate species are given in table 2.

Several groups of flagellate species are separated according of the obtained data.

Ancyromonas sigmoides, G. truncata, Rhynchomonas nasuta and Rhynchobodo simius are euryecic against the registrable factors (table 2, fig. 2).

Apusomonas proboscidea, B. globosus, B. saltans, C. longicauda, H. reniformes, M. ovata, Notosolenus sp., Paraphysomonas vestita, Petalomonas pusilla, Protaspis simplex and $S$. vivipara are stenoionic in relation to operating $\mathrm{pH}$ as they occur only under $\mathrm{pH}$ higher than 5.8 (table 2, fig. 3). All other species are euryionic.

The majority of investigated flagellate species are weakly sensitive to oxygen concentration in water. Only three species, Allantion tachyploon, Paraphysomonas vestita and Protaspis simplex are stenooxidic and were registrated under oxygen concentration not exceeding $5.6 \mathrm{mg}$ per liter (table 2, fig. 4). 
Table 2. The abiotic factor ranges in different heterotrophic flagellate species

Т аблиц 2. Диапазоны значений абиотических факторов, при которых зарегистрированы виды гетеротрофных флагеллат

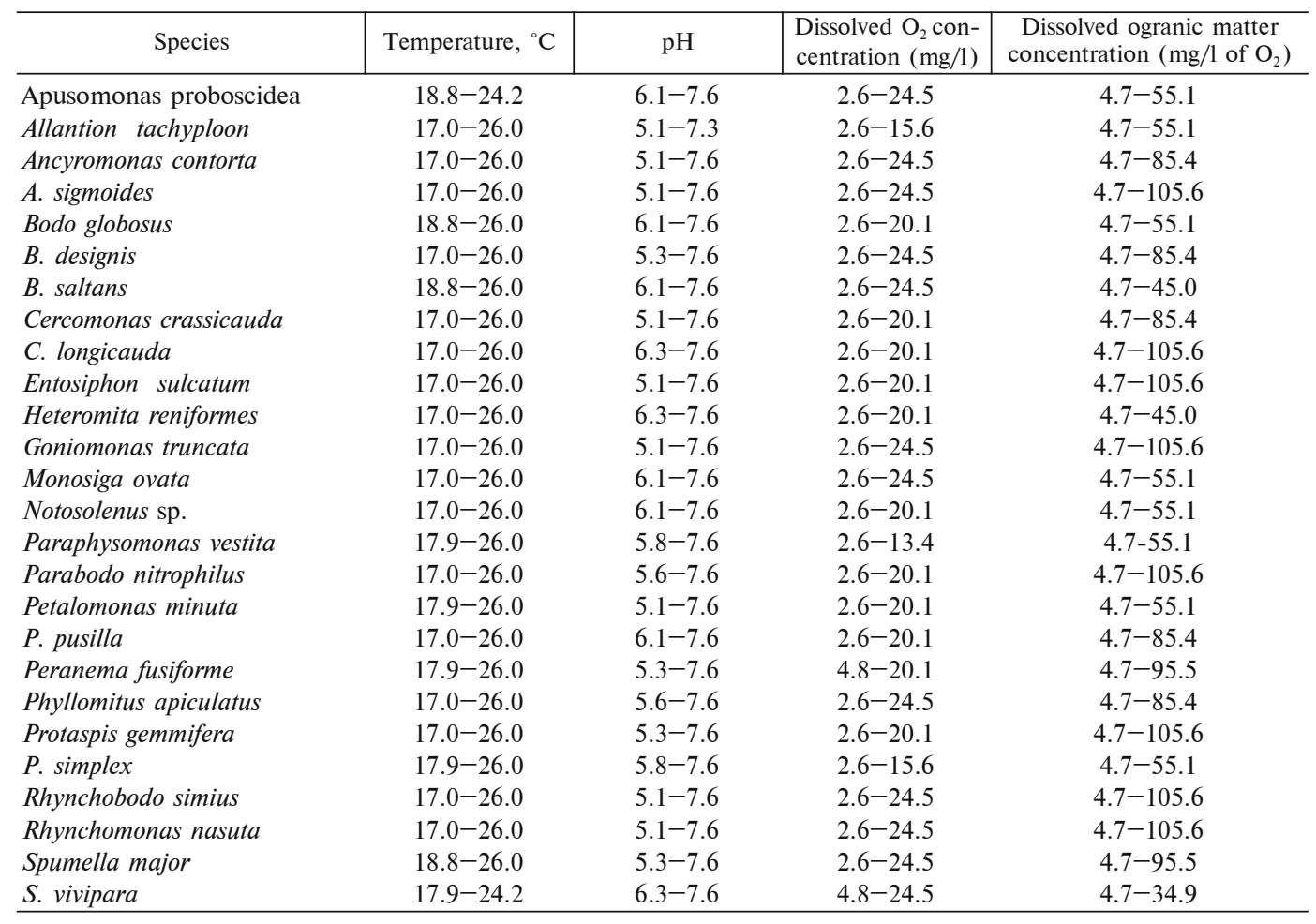
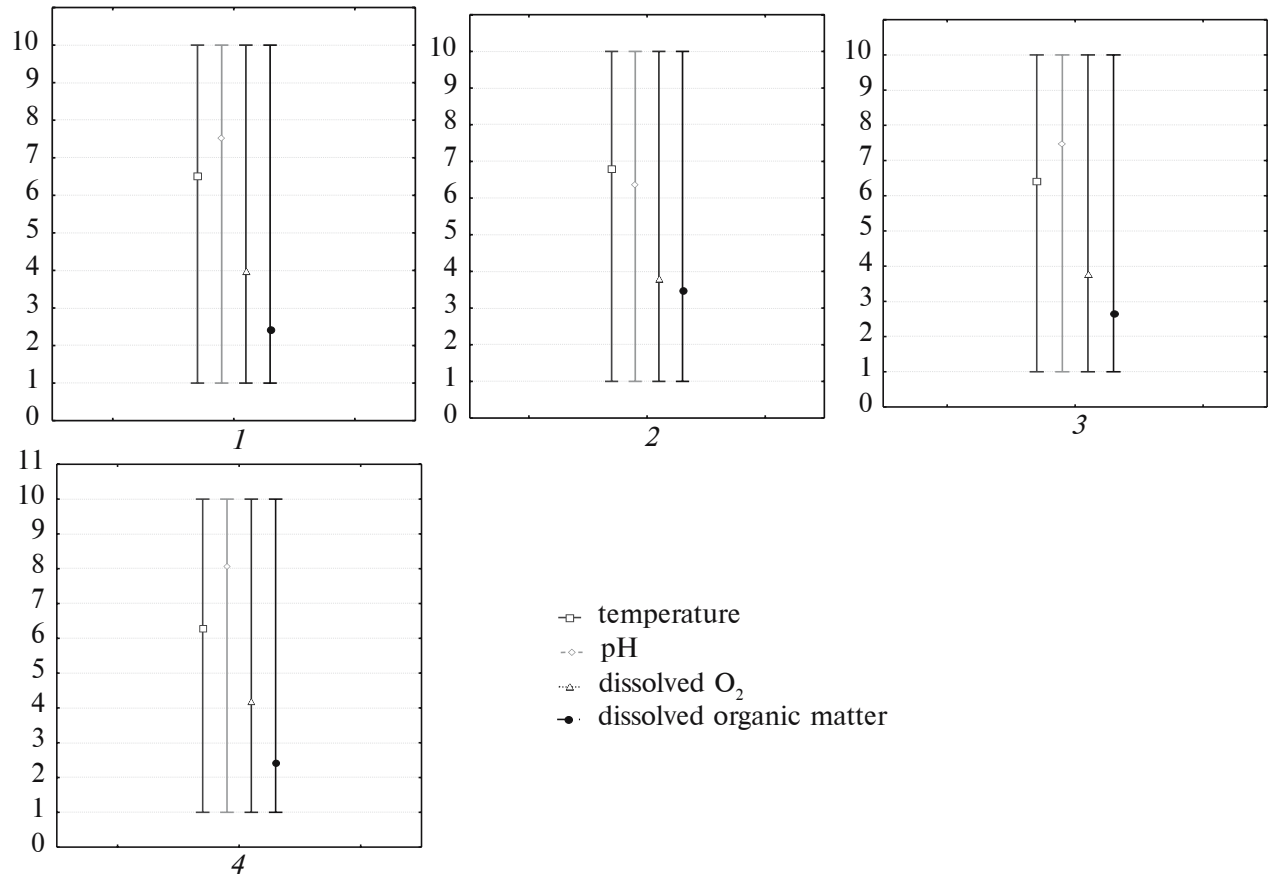

$\rightarrow$ temperature

pH

.... dissolved $\mathrm{O}_{2}$

•. dissolved organic matter

Fig. 2. Ecological spectrums of euryecic species: 1 - Rhynchobodo nasuta; $2-$ R. similis; 3 - Goniomonas truncata; 4 - Ancyromonas sigmoides.

Рис. 2. Экологические спектры эврибионтных видов: 1 - Rhynchobodo nasuta; 2 - R. similis; 3 Goniomonas truncata; 4 - Ancyromonas sigmoides. 

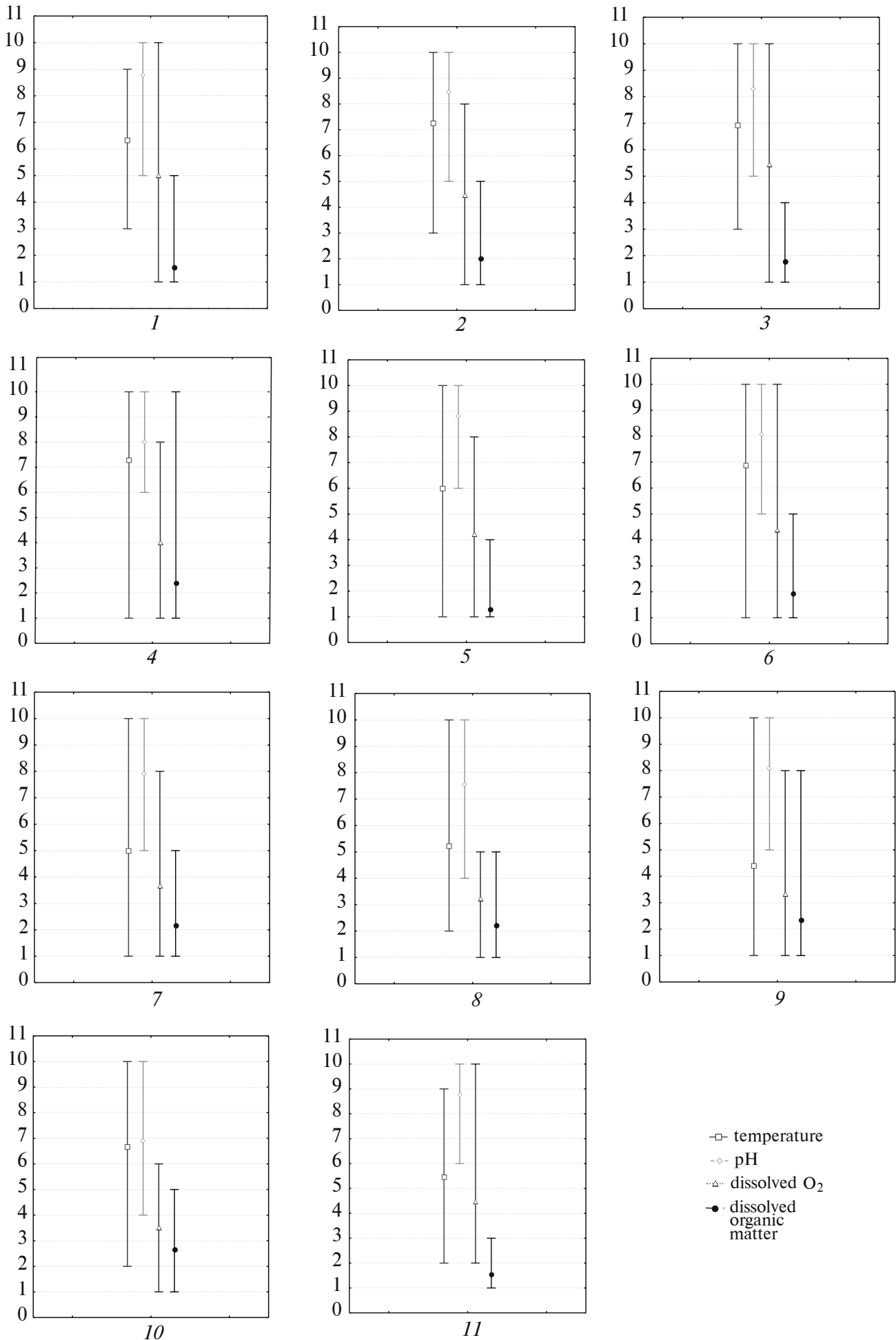

$$
\begin{aligned}
& \rightarrow-\text { temperature } \\
& -\mathrm{pH} \\
& \cdots \bullet \text { dissolved } \mathrm{O}_{2} \\
& \rightarrow \text { dissolved } \\
& \text { organic } \\
& \text { matter }
\end{aligned}
$$

Fig. 3. Ecological spectrums of stenoionic species: 1-Apusomonas proboscidea; 2 - Bodo globosus; 3B. saltans; 4 - Cercomonas longicauda; 5 - Heteromita reniformes; 6 - Monosiga ovata; 7 - Notosolenus sp.; 8 - Paraphysomonas vestita; 9 - Petalomonas pusilla; 10 - Protaspis simplex; 11 - Spumella vivipara.

Рис. 3. Экологические спектры стеноионных видов: 1 - Apusomonas proboscidea; 2 - Bodo globosus; 3 B. saltans; 4 - Cercomonas longicauda; 5-Heteromita reniformes; 6 - Monosiga ovata; 7 - Notosolenus sp.; 8- Paraphysomonas vestita; 9 - Petalomonas pusilla; $10-$ Protaspis simplex; 11 - Spumella vivipara. 

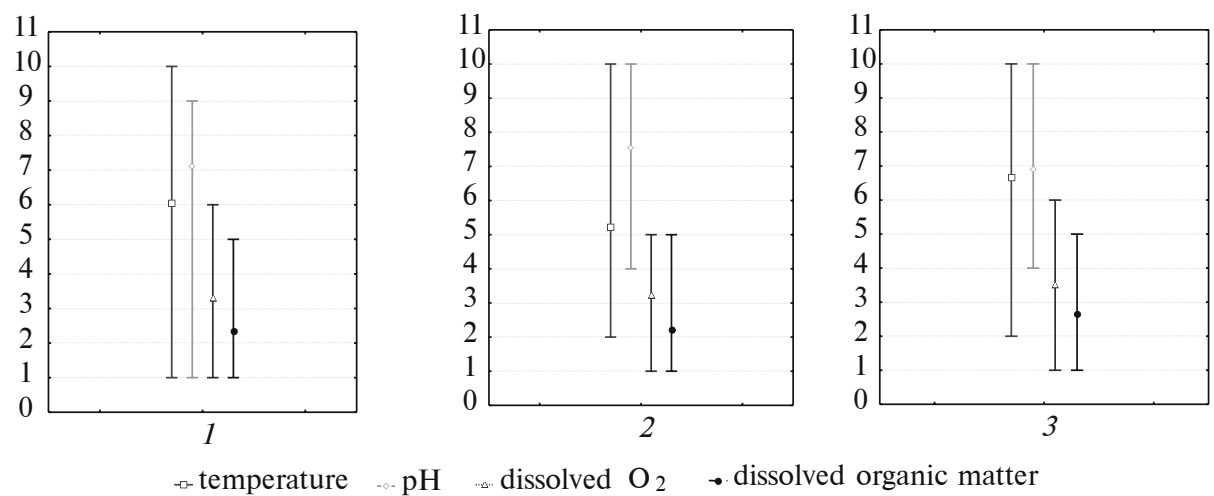

Fig. 4. Ecological spectrums of stenooxide species: 1-Allantion tachyploon; 2 - Paraphysomonas vestita; 3 - Protaspis simplex.

Рис. 4. Экологические спектры стенооксидных видов: 1 - Allantion tachyploon; 2 - Paraphysomonas vestita; 3 - Protaspis simplex.

Apusomonas proboscidea, Allantion tachyploon, B. globosus, B. saltans, H. reniformes, M. ovata, Notosolenus sp., Paraphysomonas vestita, Petalomonas pusilla, Protaspis simplex and $S$. vivipara are sensitive to dissolved organic concentration (table 2 and fig. 5) and were observed only under permanganate oxidation higher than $55.1 \mathrm{mg}$ of $\mathrm{O}_{2}$ per liter. All other species were registered under concentrations of organic matter ranged from 4.7 to $105.6 \mathrm{mg}$ of $\mathrm{O}_{2}$ per liter.

Attitude of heterotrophic flagellates to water temperature was illustrated but not analyzed using the linear scale as the material was collected in the summertime, when temperatures were from 17 to 26 centigrade degrees, i.e., with slightly sizable changes.

Clearly the configurations of ecological spectrums in separate species are determined by relations of the species to the any factors. However such relations were determined only for certain species.

Thus the reliable negative correlation was found in $A$. tachyploon between its abundance and oxygen concentration $(\mathrm{r}=-0.62)$ and positive correlation found between development of $P$. simplex and permanganate oxidation $(\mathrm{r}=0.64)$.

As it was discussed earlier Ancyromonas sigmoides, G. truncata, Rhynchomonas nasuta and Rhynchobodo simius are eurybionts. The same species previously (Shevchuk, 2007 ) were assigned to eurytopic since was encountered in all types of water bodies that are characteristic for Ukrainian Polissya.

Protozoans are known to be able to rapid adaptations for changing of environmental conditions. One can envision that the ecological spectrums of eurybiontic heterotrophic flagellates will differs in the various water bodies characteristic by various complexes of hydrochemical characteristics.

As a check on the conjecture we have obtained the ecological spectrums of listed euryecic species in the different modes of water bodies.

Referring to figure 6 the A. sigmoides was found in rivers and lakes under closely related $\mathrm{pH}$ values. In such localities $A$. sigmoides to proven to be euryionic whereas in ponds, soil-reclamation canals (under $\mathrm{pH} \geq 6.1$ ) and bogs (under $\mathrm{pH}=6.1-6.3$ ) the species is stenoionic.

The same species was euryoxide in the rivers and land reclamation canals, whereas it was stenooxide in ponds, lakes where oxygen concentrations were less then $13.4 \mathrm{mg}$ per liter and especially in bogs where it was found at $\mathrm{O}_{2}$ concentration from 2.6 to $4.7 \mathrm{mg}$ per liter.

With respect to dissolved organic matter concentration $A$. sigmoides was shown to be stenobiont only in land reclamation canals, where it was registered in the range of permanganate oxidation from 4.7 to $14.7 \mathrm{mg} \mathrm{O}_{2}$ per liter. 

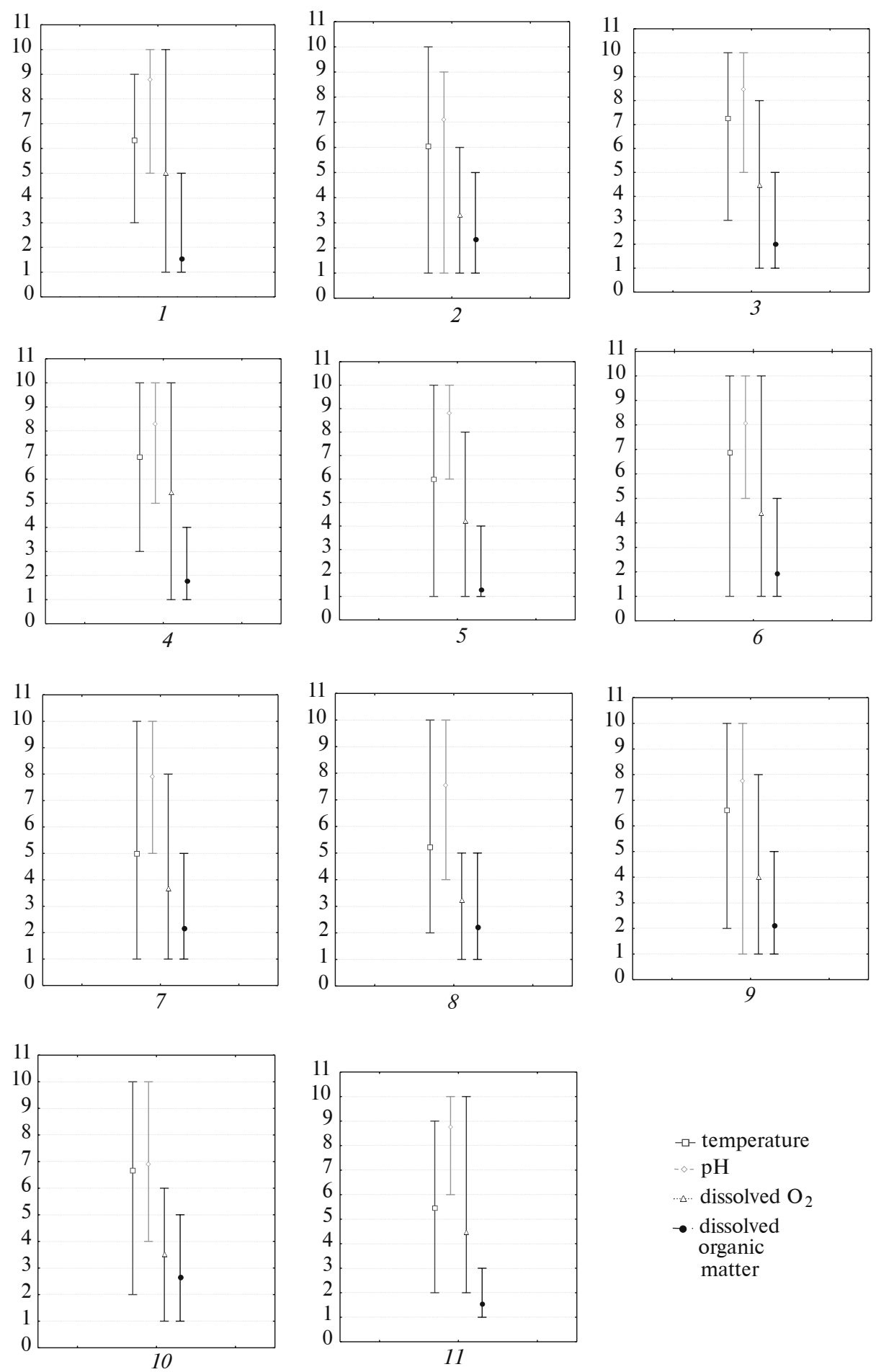

$$
\begin{aligned}
& -\square \text { temperature } \\
& -\diamond-\mathrm{pH} \\
& \cdots \cdots \text { dissolved } \mathrm{O}_{2} \\
& \rightarrow \text { dissolved } \\
& \text { organic } \\
& \text { matter }
\end{aligned}
$$

Fig. 5. Ecological spectrums of species sensitive to dissolved organic: 1 - Apusomonas proboscidea; 2 - Allantion tachyploon; 3 - Bodo globosus; 4-B. saltans; 5-Heteromita reniformes; 6-Monosiga ovata; 7 - Notosolenus sp.; 8- Paraphysomonas vestita; 9- Petalomonas minuta; 10 - Protaspis simplex; $11-$ Spumella vivipara.

Рис. 5. Экологические спектры видов, чувствительных к концентрации растворенной органики: 1 Apusomonas proboscidea; 2 - Allantion tachyploon; 3 - Bodo globosus; $4-$ B. saltans; 5 - Heteromita reniformes; 6- Monosiga ovata; 7- Notosolenus sp.; 8- Paraphysomonas vestita; 9- Petalomonas minuta; 10 - Protaspis simplex; $11-$ Spumella vivipara. 

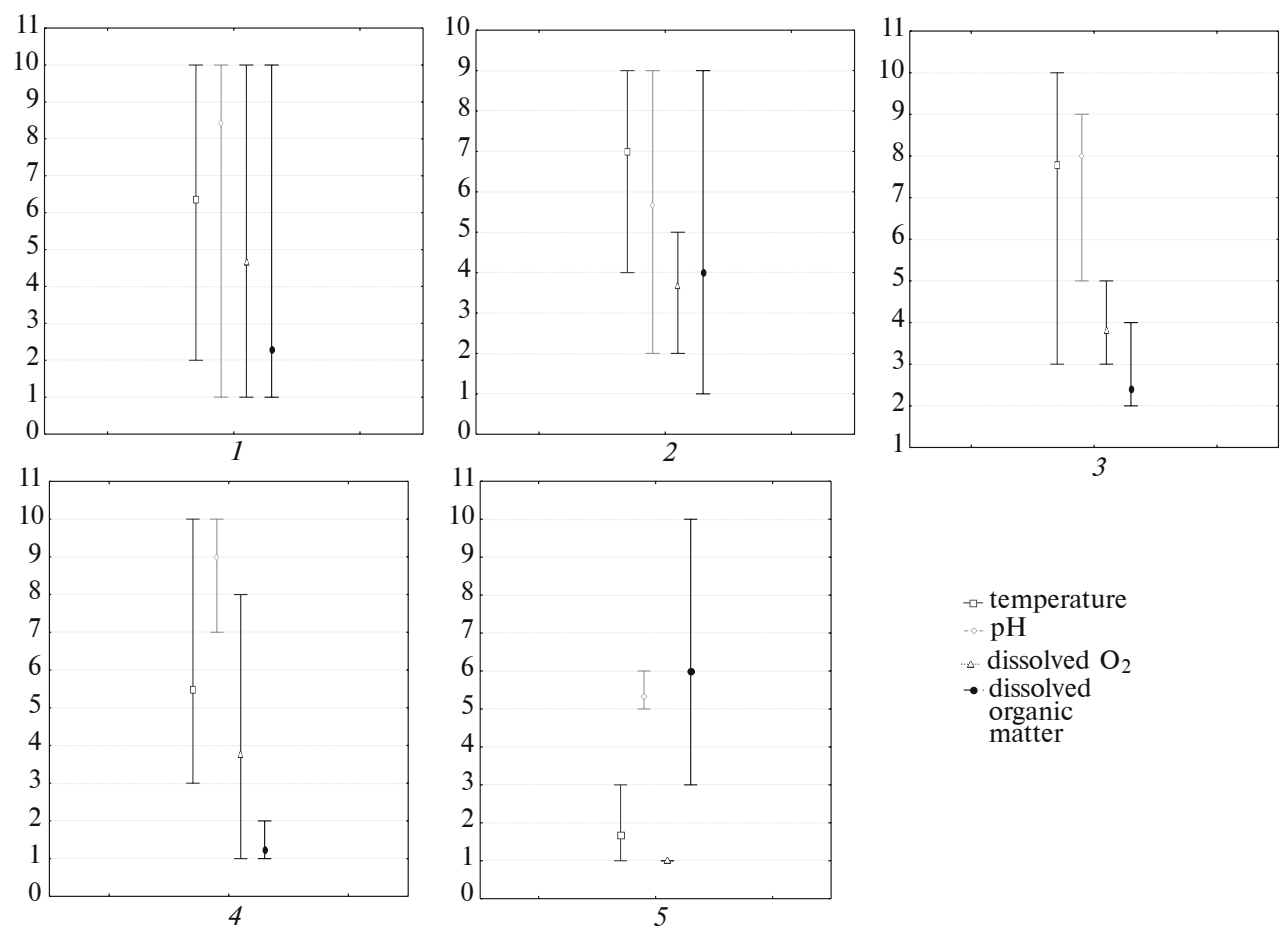

$$
\begin{aligned}
& \text { - temperature } \\
& \text { pH } \\
& \text { dissolved } \mathrm{O}_{2} \\
& \text { - dissolved } \\
& \text { organic } \\
& \text { matter }
\end{aligned}
$$

Fig. 6. Ecological spectrums of Ancyromonas sigmoides in water bodies of diferent modes: 1 - rivers; $2-$ lakes; 3 - ponds; 4 - soil-reclamation canals; 5 - bogs.

Рис. 6. Экологические спектры Ancyromonas sigmoides в водоемах разных типов: 1 - реки; 2 - озера; 3 - пруды; 4- каналы; 5- болота.
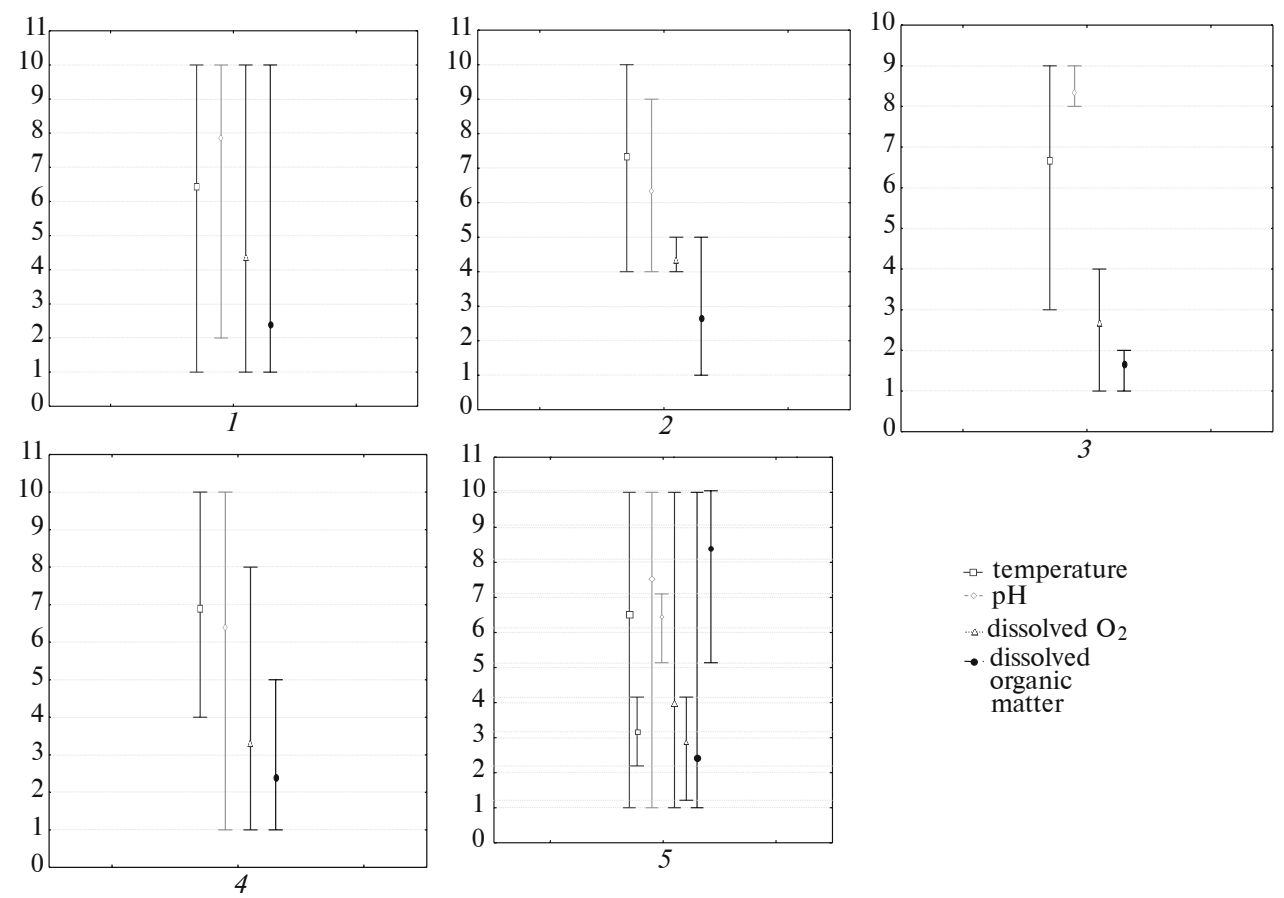

Fig. 7. Ecological spectrums of Rhynchobodo nasuta in water bodies of diferent modes: 1 - rivers; 2 - lakes; 3 - ponds; 4 - soil-reclamation canals; 5- bogs.

Рис. 7. Экологические спектры Rhynchobodo nasuta в водоемах разных типов: 1 - реки; 2 - озера; 3 пруды; 4 - каналы; 5 - болота. 
The similar differences in attitudes regarding to hydrochemical factors in various water bodies were observed in other eurybionts.

For instance, $R$. nasuta was found as euryionic in the rivers and canals and as stenoionic in ponds, bogs and lakes (fig. 7). It was also noted as euryoxide in rivers and canals but as stenooxide in bogs and lakes.

It is interesting that in rivers and bogs $R$. nasuta was registered at permanganate oxidation that excess of $55.1 \mathrm{mg} \mathrm{O}_{2}$ per liter, whereas in ponds, land reclamation canals and lakes at values of the parameter not exceeding this quantity (fig. 7).

In partcular, $R$. simius occurs in lakes over the operating $\mathrm{pH}$ from 5.3 to 6.3 . As regards to dissolve oxygen the species was registered under its volume no more than $15.6 \mathrm{mg}$ per liter in all types of water bodies except rivers.

$R$. simius was registered in rivers, ponds and bogs similarly to $R$. nasuta at permanganate oxidation that exceeeds certain level, but at values of the parameter less than this quantity in land reclamation canals and lakes. However, for $R$. nasuta threshold value was different and not exceeding $65.2 \mathrm{mg} \mathrm{O}_{2}$ per liter (fig. 8).
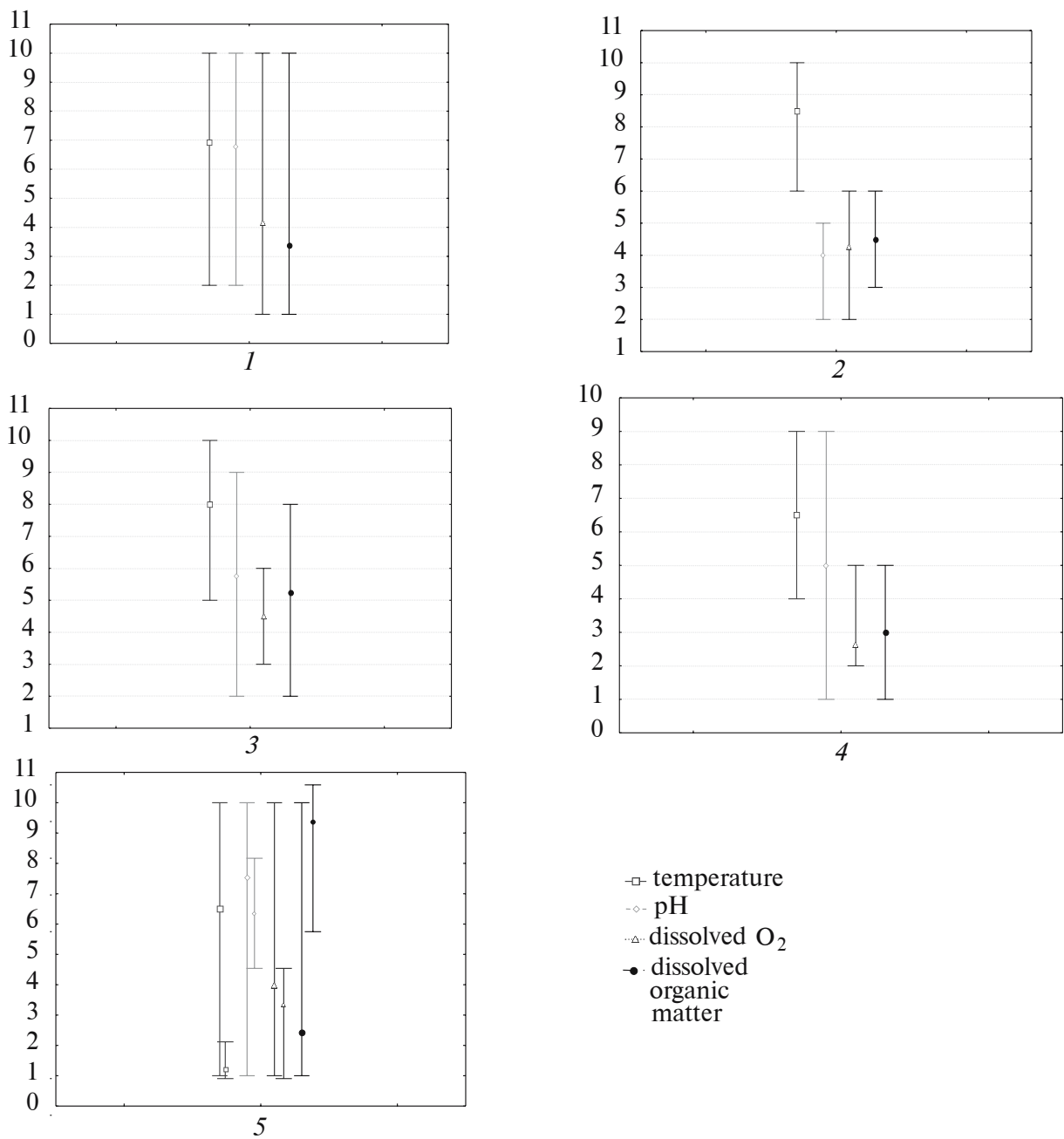

Fig. 8. Ecological spectrums of Rhynchobodo similis in water bodies of diferent modes: 1 - rivers; 2 - lakes; 3 - ponds; 4 - soil-reclamation canals; 5 - bogs.

Рис. 8. Экологические спектры Rhynchobodo similis в водоемах разных типов: 1 - реки; 2 - озера; 3 пруды; 4- каналы; 5- болота. 

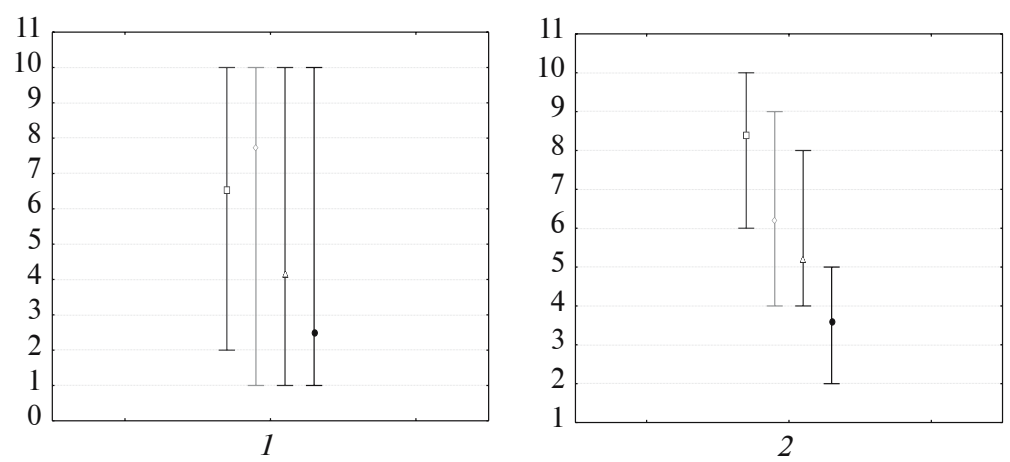

$\square-$ temperature

$\diamond-\mathrm{pH}$

.... dissolved $\mathrm{O}_{2}$

$\rightarrow$ dissolved organic matter
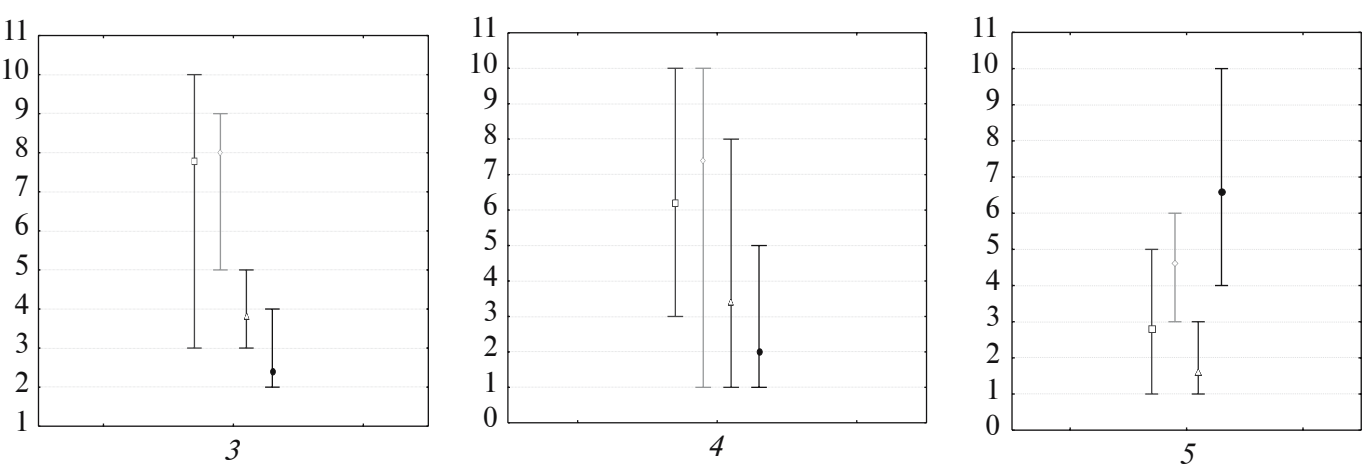

Fig. 9. Ecological spectrums of Goniomonas truncata in water bodies of diferent modes: 1 - rivers; 2 - lakes; 3 - ponds; 4 - soil-reclamation canals; 5 - bogs.

Рис. 9. Экологические спектры Goniomonas truncata в водоемах разных типов: 1 - реки; $2-$ озера; 3 - пруды; 4- каналы; 5- болота.

Finally, G. truncata is shown to be euryionic in rivers and land reclamation canals, whereas in ponds, bogs and lakes it was found to be stenoionic (fig. 9).

This species also shows reduction of tolerance to oxygen concentration in ponds and bogs, where it was found at range from 2.6 to $13.4 \mathrm{mg} \mathrm{O}$ per liter. At the same time, G. truncata is eurybiotic in the rivers and bogs in respect to permanganate oxidation whereas in lakes, ponds and canals occurs only under range from 4.7 to $55.1 \mathrm{mg}$ $\mathrm{O}_{2}$ per liter (fig. 9).

Hence the narrowing of existence spectrums in certain types of water bodies characteristic for investigated species of heterotrophic flagellates was detected. The peculiarity is especially expressed in bogs, possessing specific complex of hydrochemical conditions.

This study was supported by mutual grant of the Fundamental Researches State Fund of Ukraine and Russian Foundation of Basic Research (project No. Ф28/523-2009).

Alekin O. A., Semenov A. D., Skopintcev B. A. Rukovodstvo po khimicheskomu analizu sushi. - Moskow : Gidrometeoizdat, 1973. - 269 p. - Russian : Алекин О. А., Семенов А. Д., Скопинцев Б. А. Руководство по химическому анализу суши.

Asaul Z. I. Vyznachnyk evglenovykh vodorostej Ukrains'koi RSR. - Kyiv : Nauk. dumka, 1975. - 407 p. Ukrainian : Асаул 3. I. Визначник евгленових водоростей Української РСР.

Fenchel T. The ecology of Protozoa. Berlin: Madison/Springer-Verlag, 1987. - $197 \mathrm{~S}$.

Kosolapova N. G. Soobshchestva planktonnykh geterotrofnykh zhgutikonostcev malykh vodnykh ob'ektov // Thesis for the degree of the candidate of biological sciences. - Borok : IBIW, 2005. - $205 \mathrm{p}$. Russian : Косолапова H. Г. Сообщества планктонных гетеротрофных жгутиконосцев малых водных объектов : Автореф. дис. ... канд. биол. наук.

Mylnykov A. P. Some taxonomic features of cercomonadidae // Biology of Inland Waters. Inform. Bull. 1992. - N 93. - P. 35-39. - Russian with English summary : Мыльников А. П. Некоторые таксономические признаки церкомонадид // Биол. внутр. вод. Информ. бюл. ИБВВ РАН. 
Mylnikov A. P., Kosolapova $N$. G. The fauna of heterotrophic flagellates in a small boggy lake // Biologiya vnutrennih vod. - 2004. - N 4. - P. 18-28. - Russian with English summary : Мыльников А. П., Косолапова Н. Г. Фауна гетеротрофных жгутиконосцев небольшого заболоченного озера // Биол. внутр. вод. Информ. бюл. ИБВВ РАН.

Pesenko $Y$ u. A. Printcipy i metody kolichestvennogo analiza v faunisticheskikh issledovaniyakh. - Moskow : Nauka, 1982. - 285 p. - Russian : Песенко Ю. А. Принципы и методы количественного анализа в фаунистических исследованиях.

Shevchuk $S$. Yu. Distribution of heterotrophic flagellates in different water reservoirs of the central part of Ukrainian Polissya area // Vestnik zoologii. - 2007. - 41, N 5. - P. 463-468. - Russian with English summary : Шевчук С. Ю. Распределение гетеротрофных жгутиконосцев в водоемах разного типа в центральной части Украинского Полесья // Вестник зоологии.

Tikhonenkov D. V. Fauna, morphologiya i structura soobshchestv svobodnozhyvushchikh geterotrofnykh zhgutikonostcev $\mathrm{v}$ raznotipnykh presnovodnykh i morskikh biotopakh // Thesis for the degree ... of the Candidate of biological sciences. - Borok : IBIW, 2006. - 397 p. - Russian : Тихоненков Д. В. Фауна, морфология и структура сообществ свободноживущих гетеротрофных жгутиконосцев в разнотипных пресноводных и морских биотопах : Автореф. дис. ... канд. биол. наук.

Unifitcirovannye metody issledovaniya kachestva vody. Part 3. Methgody biologiocheskogo analiza vod. Moskow: CMEA, 1983. - 371 p. - Russian : Унифицированные методы исследования качества воды. Ч. 3. Методы биологического анализа вод.

Zhukov B. F. Atlas of freshwater heterotrophic flagellates (biology, ecology, taxonomy). - Rybinsk : Rybinskyi Dom Pechati, 1993. - 160 p. - Russian : Жуков Б. Ф. Атлас пресноводных гетеротрофных жгутиконосцев (биология, экология и систематика). 